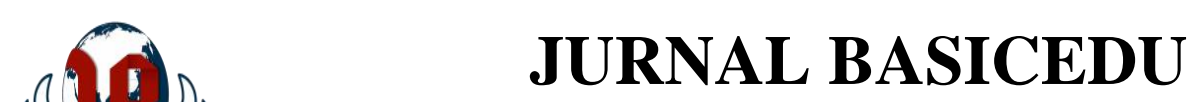

Volume 5 Nomor 4 Tahun 2021 Halaman 2449 - 2460

Research \& Learning in Elementary Education

https://jbasic.org/index.php/basicedu

PAVERATAS

\title{
Pengembangan Media Poly Game pada Pembelajaran Matematika dalam Meningkatkan Kemampuan Pemecahan Masalah di Sekolah Dasar
}

\author{
Denise Dwi Rahmatania $^{1 凶}$, Yohana Setiawan $^{2}$ \\ Universitas Kristen Satya Wacana, Indonesia ${ }^{1,2}$ \\ E-mail: 292017022@ @student.uksw.edu ${ }^{1}$,yohana.setiawan@uksw.edu ${ }^{2}$
}

\begin{abstract}
Abstrak
Adanya masa pandemic COVID 19 mengharuskan semua kegiatan pembelajaran dilaksanakan secara daring. Namun sebagian guru belum maksimal dalam memanfaatkan teknologi dalam kegiatan pembelajaran. Hal ini membuat siswa menjadi tidak antusias dalam mengikuti kegiatan pembelajaran. Tujuan dari penelitian ini yaitu mengetahui tingkat validitas produk pengembangan media pembelajaran poly game pada pembelajaran matematika dalam meningkatkan kemampuan pemecahan masalah bangun datar siswa SD Kelas IV. Jenis penelitian ini adalah pengembangan atau Research and Development (R\&D). Penelitian dilaksanakan dengan menggunakan model desain pengembangan ADDIE yaitu Analysis, Design, Development, Implementation, dan Evaluation. Data hasil uji validasi yang dilakukan oleh ahli diperoleh hasil sebagai berikut: (1) presentase yang diperoleh dari uji validasi materi sebesar 78,1\% dengan kategori tinggi; (2) presentase yang diperoleh dari uji validasi media sebesar 93,7\% dengan kategori tinggi. Berdasarkan uji validasi yang telah dilakukan oleh ahli materi dan ahli media, maka dapat disimpulkan bahwa media pembelajaran poly game pada pembelajaran matematika dalam meningkatkan kemampuan pemecahan masalah bangun datar siswa SD Kelas IV dapat dikatakan valid untuk digunakan.
\end{abstract}

Kata Kunci: game, matematika, kemampuan pemecahan masalah.

\begin{abstract}
Due to the COVID-19 pandemic, all learning activities were carried out online. However, some teachers had not been maximal in utilizing technology in learning activities. This made students less enthusiastic in participating in learning activities. The purpose of this study was to determine the level of product validity of the development of poly game learning media in mathematics learning to improve problem solving ability of elementary school students in Grade IV. This was research and development $(R \& D)$ using ADDIE development design model, namely Analysis, Design, Development, Implementation, and Evaluation. The results of the validation test conducted by experts obtained the following results: (1) the percentage obtained from the material validation test was $78.1 \%$ with a high category; (2) the percentage obtained from the media validation test was $93.7 \%$ in the high category. Based on the validation tests by material experts and media experts, it could be concluded that the poly game learning media was valid to be used in mathematics learning in improving the problem solving ability of Grade IV elementary school students.
\end{abstract}

Keywords: games, math, problem solving skills.

Copyright (c) 2021 Denise Dwi Rahmatania, Yohana Setiawan

Corresponding author :

Email : 292017022@student.uksw.edu

DOI : https://doi.org/10.31004/basicedu.v5i4.1249

ISSN 2580-3735 (Media Cetak)

ISSN 2580-1147 (Media Online)

Jurnal Basicedu Vol 5 No 4 Tahun 2021

p-ISSN 2580-3735 e-ISSN 2580-1147 


\section{PENDAHULUAN}

Aspek kehidupan yang amat dasar bagi pembangunan suatu negara adalah pendidikan. Menurut (Zulkarnain, 2015) pendidikan adalah suatu cara atau upaya yang dilaksanakan oleh keluarga, masyarakat, serta pemerintah lewat pendampingan, pelatihan, pembelajaran yang berjalan di sekolah maupun diluar sekolah. Dengan adanya pendidikan dapat menumbuhkan dan memajukan kualitas sumber daya manusia yang ada dalam suatu negara. Pemerintah telah mengupayakan berbagai macam cara agar meningkatkan kualitas sumberdaya manusia mulai dari pelatihan peningkatan kualitas guru, penyempurnaan kurikulum, serta penyediaan sarana dan prasarana yang mendukung mutu pendidikan di Indonesia. Contoh upaya pemerintah dalam meningkatkan mutu pendidikan adalah dengan melakukan inovasi kurikulum yaitu menerapkan kurikulum 2013 sebagai penyempurna kurikulum 2006 atau KTSP.

Berdasarkan Undang-Undang No 20 Tahun 2003 kurikulum merupakan seperangkat konsep dan penyusunan tentang isi, tujuan, bahan pelajaran, serta cara yang dimanfaatkan untuk petunjuk dalam pelaksanaan kegiatan pembelajaran supaya tujuan pendidikan tercapai. Demi mempersiapkan generasi bangsa supaya mempunyai daya hidup menjadi manusia yang beriman, kreatif, produktif, inovatif, dan afektif serta dapat mengabdi pada kehidupan bermasyarakat, berbangsa, bernegara dan peradaban dunia maka kurikulum 2013 diciptakan. Dalam kurikulum 2013 terdapat keterampilan abad 21 atau 4C (Creative, Critical thinking, Communicative, dan Collaborative), siswa akan dituntut untuk kreatif, berpikir kritis, komunikasi, dan kolaborasi. Selain itu kurikulum 2013 juga menuntut siswa untuk mempunyai kemampuan pemecahan masalah.

Pada pertengahan tahun 2020 ini proses pembelajaran terhambat karena adanya pendemi COVID 19 yang menyebabkan peserta didik melakukan pembelajaran daring. Menurut (Kosasih, 2014), pembelajaran merupakan cara yang dimilik seorang guru dengan membutuhkan pengetahuan professional untuk mewujudkan seseorang supaya dapat mencapai tujuan kurikulum. Pembelajaran daring atau pembelajaran jarak jauh merupakan pembelajaran yang dilakukan dengan cara online, dan memanfaatkan aplikasi pembelajaran maupun jejaring sosial. Pada saat pandemi COVID 19 ini guru diharuskan dapat menggunakan teknologi semaksimal mungkin supaya mendukung berlangsungnya proses pembelajaran, contohnya dengan memanfaatkan aplikasi zoom, google meet, google form, WhatsApp group, dan guru bisa menggunakan sebuah aplikasi game edukasi untuk membantu proses pembelajaran serta menarik minat siswa untuk semangat dalam belajarnya. Dari observasi dan angket yang dibagikan pada beberapa guru di SDN Tegalrejo 05 selama pandemi guru menggunakan media pembelajaran berupa video dari youtube dan memanfaatkan WhatsApp Group untuk memberikan tugas. Untuk penggunaan game edukasi belum ada dalam pembelajaran meskipun sebagian besar memahami bahwa game edukasi perlu digunakan karena dapat menarik minat belajar siswa saat pembelajaran daring, meningkatkan berpikir kritis anak, dan meningkatkan kemampuan pemecahan masalah siswa pada kehidupan sehari - hari, serta game edukasi dapat membantu siswa mengerti tentang materi yang diajarkan guru sehingga hasil belajar siswa akan lebih maksimal. Saat ini minat belajar siswa perlu ditingkatkan apalagi dengan pembelajaran daring yang jauh dari jangkauan guru harus tetap mengajarkan pelajaran SD yang pada umumnya seperti Bahasa Indonesia, Agama, PPKn, IPA, IPS, SBdP, Penjaskes, Bahasa Inggris, Bahasa Daerah, dan Matematika. Tidak semua siswa memahami dan mengerti tentang pelajaran yang diajarkan pasti siswa mempunyai kendala pada beberapa mata pelajaran yang diajarkan (Mastura \& Santaria, 2020).

Adanya masa pandemic COVID 19 guru dituntut untuk melakukan pembelajaran secara daring sehingga harus memanfaatkan semaksimal mungkin teknologi yang sudah tersedia. Menurut Ardiansyah, (2013) mengutarakan bahwa e - learning merupakan proses kegiatan belajar mengajar yang dilakukan dengan memanfaatkan teknologi elektronik sehingga pendidik dengan siswa tidak bertatap muka secara langsung. Jadi, dapat disimpulkan bahwa E-learning adalah suatu sistem proses pembelajaran jarak jauh tanpa harus melakukan tatap muka antara pendidik dengan siswa. Saat ini guru telah berupaya melakukan proses belajar mengajar dengan daring yaitu melalui whatsapp group, mengirimkan video pembelajaran, dan melakukan tatap muka 
lewat aplikasi. Dengan pembelajaram daring ini guru mempunyai dua tanggung jawab yaitu meningkatkan minat belajar siswa dan membantu siswa memahami setiap materi yang sedang diajarkan. Dalam sekolah dasar pembelajaran yang harus dipahami adalah matematika.

Menurut Wijayanti (2011), matematika adalah ilmu mengenai bentuk, kuantitas, susunan, dan ukuran yang pokok yaitu cara dan proses untuk menemukan melalui rancangan yang tepat dan symbol yang konsisten, sifat dan keterlibatan antara ukuran dan jumlah, baik dengan abstrak, matematika murni atau dalam keterkaitan manfaat pada matematika terapan. Namun banyak siswa yang kurang memahami pelajaran matematika untuk itu agar siswa menjadi semangat belajar dan memahami materinya meskipun pembelajaran daring guru harus berinovasi membuat model atau media pembelajaran yang berbeda dengan pembelajaran di kelas. Sehingga dapat menarik minat siswa sekaligus membantu siswa memahami materinya. Peran penting matematika diakui Cockroft (Shadiq, 2014) yaitu "It would be very difficult-perhaps impossible-to live a normal life in very many parts of the world in the twentieth century without making use of mathematics of some kind" dengan kata lain akan sangat sulit atau tidaklah mungkin bagi seseorang untuk hidup dibagian bumi ini pada abad ke-20 tanpa sedikitpun memanfaatkan matematika. Oleh karena itu, untuk siswa menguasai matematika harus dilakukan dengan cara membangun sistem pembelajaran matematika yang aktif, kreatif dan inovatif sehingga dapat membuat siswa aktif dalam proses pembelajaran. Matematika merupakan muatan pelajaran yang dirasa susah oleh sebagian siswa di sekolah. Namun, pada segi lain matematika dirasa mempunyai istimewa karena fungsinya sebagai prediktor yang berdampak bagi siswa untuk menempuh sekolah formal dibanding keterampilan lainnya. Pada muatan pelajaran matematika terdapat salah satu keterampilan yang perlu dimiliki adalah kemampuan pemecahan masalah. Menurut Permendikbud No. 64 Tahun 2013, pemecahan masalah ialah aspek kompetensi yang perlu dipahami oleh peserta didik di Indonesia. Namun untuk meningkatkan kemampuan memecahkan masalah pada peserta didik dibutuhkan proses pembelajaran yang mendukung tetapi saat ini di Indonesia masih banyak guru yang menerapkan proses pembelajaran metode ceramah. Dengan metode ceramah dan menoton mengakibatkan siswa kurang bersemangat di dalam proses pembelajaran dan kurang mampu meningkatkan kemampuan pemecahan masalah dengan sendirinya. Menurut Robert L. Solso (Mawwaddah, 2015), pemecahan masalah adalah suatu pemikiran yang terarah secara langsung untuk menemukan solusi atau jalan keluar suatu masalah yang spesifik. Menurut Polya ((Desi Indarwati, Wahyudi, 2014) pemecahan masalah merupakan suatu usaha untuk menemukan jalan keluar dari suatu kesulitan dan mencapai tujuan yang tidak dapat dicapai dengan segera. Sehingga dapat disimpulkan bahwa pemecahan masalah adalah suatu usaha untuk menemukan jalan keluar dari masalah. Menurut Wahyudi \& Anugraheni, (2017) terdapat dua macam soal pemecahan masalah yaitu soal rutin dan soal non rutin. Soal pemecahan masalah rutin ini terdapat aplikasi suatu prosedur matematika yang biasanya dipelajari, sedangkan soal pemecahan masalah non rutin biasanya memerlukan pemikiran yang lebih dalam untuk mencapai prosedur matematika. Berikut ini pemaparan strategi atau langkah - langkah pemecahan masalah menurut Polya (dalam Wahyudi \& Anugraheni, 2017) antara lain: (1) Memahami Masalah, langkah pertama untuk memecahkan masalah adalah memahami masalah atau memahami soal. Peserta didik harus memahami apa yang mereka hadapi, apa yang tidak diketahui, bagaimana situasi soal, bagaimana hubungan jumlah, nilai yang terkait dengan apa yang mereka cari. (2) Membuat Rencana, pada langkah kedua dengan membuat suatu perencanaan untuk menyelesaikan suatu masalah, yaitu siswa dapat mencari operasi atau cara untuk menyelesaikan masalah atau soal. Siswa dapat mengidentifikasi masalah, menebak, membuat diagram atau tabel, menyederhanakan masalah, atau menguji suatu kemungkinan. (3)Melaksanakan Rencana, dalam langkah ketiga ini peserta didik hanya melaksanakan rencana yang sudah disusun pada langkah kedua dengan konsisten. Peserta didik juga harus memeriksa apakah langkah yang digunakan sudah benar dan tepat untuk menyelesaikan masalah. (4) Memeriksa Kembali, langkah keempat adalah memeriksa kembali jawaban yang sudah diperoleh. Kemudian peserta didik dapatkah memperoleh hasil yang sama dengan cara yang berbeda. 
Berdasarkan penelitian yang dilakukan oleh Widyastuti (2019) mengemukakan bahwa secara umum 22, $58 \%$ siswa mempunyai minat terhadap matematika dengan kategori tinggi, 76, $56 \%$ kategori sedang, dan 0,86 $\%$ dalam kategori rendah. Sedangkan hasil penelitian yang dilakukan Jiran. dkk (2019) yaitu minat belajar siswa dalam mempelajari matematika tergolong kuat dengan mencapai presentase sebesar 68,24\%. Ada beberapa faktor pendukung seperti lingkungan belajar yang nyaman, guru memberikan motivasi pada siswa, dan perlengkapan belajar siswa. Adapun faktor penghambat yaitu guru masih monoton dalam menyempaikan materi pembelajaran.

Menurut Prensky (2012), game edukasi yaitu permainan yang dirancang untuk belajar, tetapi dengan bermain dan menyenangkan. Game edukasi merupakan perpaduan game komputer, kegiatan pendidikan, dan prinsip pembelajaran. Game edukasi adalah suatu permainan yang mempunyai tujuan menarik minat belajar siswa dengan sambil belajar, permainan ini lebih fokus pada isi dan tujuan game, sedangkan genre game tidak termasuk di dalamnya. Tujuan utama dari game edukasi yaitu meningkatkan minat belajar siswa untuk memahami materi pembelajarn yang diajarkan dengan bermain game, sehingga siswa akan senang dan tidak bosan. Media ini dapat menarik dan menyenangkan bagi siswa dalam proses pembelajaran. pada umumnya media yang masih banyak digunakan saat ini adalah buku mata pelajaran. Dimana minat baca buku oleh siswa sekarang rendah dan hal itu dapat menyebabkan pengaruh pada hasil belajar dan prestasi siswa.

Dari hasil penelitian dan pembahasan yang dilaksanakan oleh Anugrahini \& Windrawanto (2017), menyatakan bahwa produk media pembelajaran game bubble match dapat dikembangkan menggunakan desain pengembangan ADDIE dan mempermudah siswa dalam memahami materi pembagian khususnya pembagian sebagai pengurangan berulang dan menjadikan siswa lebih mandiri dalam belajar serta membuat mereka lebih aktif. Sedangkan hasil penelitian yang dilaksanakan oleh Kuncoro (2019), mengemukakan bahwa siswa dapat menerapkan gaya belajar visual dengan memainkan game secara langsung, pengembangan game matematika dikembangkan dengan menggunakan model ASSURE. Penelitian selanjutnya dilakukan oleh Sejati (2020), dapat disimpulkan pengembangan media pembelajaran basis PC game untuk meningkatkan kemampuan pemecahan masalah dinyatakan valid atau layak digunakan. Diperoleh dari hasil uji validasi materi seumlah $80 \%$, hasil uji validasi media $79,2 \%$, hasil uji validasi pembelajaran $81,2 \%$, dan hasil pakar soal 78,7 \%. Kemudian penelitian yang dilakukan oleh Savitri (2019), dapat disimpulkan bahwa kevalidan media dapat ditemukan tiga jenis yaitu kelayakan, keefektifan, dan kepraktisan. Media interaktif dapat dikatakan "valid" dan "layak" oleh hasil penilaian dari para ahli media yang memperoleh rata - rata 3,4. Kemudian hasil respon angket dikategorikan "valid" dan" sangat praktis" yang memperoleh rata-rata 3,7. Dan tingkat keefktifan media memperoleh dari hasil tes 20 siswa dan dinyatakan "valid" dan "sangat efektif" dengan hasil rata - rata 82. Jadi dapat disimpulkan dari media interaktif materi luas dan keliling bangun datar dapat dikategorikan layak digunakan dilapangan. Selanjutnya penelitian yang dilakukan oleh Amanda \& Putri (2019), Teknik pengembangan aplikasi ini memakai model ADDIE. Hasil dari menganalisis keunggulan aplikasi yang diperoleh dari hasil uji fuctional suitability memperoleh mendapat $86,6 \%$ dan uji materi sejumlah $100 \%$. Serta hasil uji usability mendapat $93,7 \%$ dari uji coba pada siswa kelas IV. Dari penjelasan diatas dapat disimpulkan game edukasi mengenal bangun datar diakui layak atau valid untuk sarana media pembalajaran siswa kelas IV.

Dari penelitian terdahulu game edukasi tidak diragukan lagi untuk mendukung proses jalannya pendidikan. Massachussets Insitute of Technology (MIT) menyatakan bahwa game benar valid digunakan untuk mengembangkan logika serta pengetahuan pemain pada suatu persoalan masalah lewat proyek game. Game edukasi akan dibuat mempunyai keunggulan yaitu didalamnya tidak hanya terdapat soal yang dijadikan sebagai permainan tetapi juga terdapat materi tentang bangun datar kelas IV SD. Game dibuat seperti game adventure dan terdapat tingkatan level. Kemudian berdasar penelitian yang telah dilakukan, media poly game memiliki keunggulan yakni game berisi soal pemecahan masalah, game menggunakan adobe animate 2020, game terdapat KD dan indikator, game berisi materi bangun datar. 
Penelitian ini mengembangkan media pembelajaran poly game pada pembelajaran matematika dalam meningkatkan kemampuan pemecahan masalah bangun datar siswa SD Kelas IV. Dalam penggunaan media pembelajaran poly game pada pembelajaran matematika khususnya materi bangun datar dapat digunakan oleh siswa kelas IV SD, sehingga dengan adanya media pembelajaran poly game ini dapat membuat siswa bersemangat dalam mengikuti kegiatan pembelajaran. Kemudian siswa lebih mudah untuk memahami materi matematika khususnya materi bangun datar. Selanjutnya dengan adanya media pembelajaran poly game diharapkan membuat kemampuan pemecahan masalah bangun datar semakin meningkat. Selanjutnya media pembelajaran poly game juga memberikan pengalaman baru bagi siswa kelas IV, karena dengan adanya poly game ini membuat siswa belajar dengan hal baru yakni belajar menggunakan media pembelajaran poly game yang dapat dimainkan di PC seperti laptop dan komputer. Dengan adanya media pembelajaran poly game ini dapat membuat siswa berantusias untuk belajar dirumah kapan saja disertai bimbingan orangtua. Selain itu, media pembelajaran poly game juga dapat dijadikan sebuah referensi dan sumber belajar bagi guru dalam penggunaan media pembelajaran khususnya materi bangun datar. Penelitian dan pengembangan ini memiliki keunikan yakni penelitian dilakukan pada masa pandemi COVID-19 yang masih ada di Indonesia, sehingga semua kegiatan pembelajaran dilaksanakan secara daring. Penelitian dan pengembangan media pembelajaran poly game pada pembelajaran matematika dalam meningkatkan kemampuan pemecahan masalah bangun datar siswa SD Kelas IV hanya dapat dilaksanakan sampai uji validitas dari ahli materi dan ahli media saja.

\section{METODE}

Penelitian dan pengembangan media pembelajaran poly game pada pembelajaran matematika dalam meningkatkan kemampuan pemecahan masalah bangun datar siswa SD Kelas IV telah dilaksanakan menggunakan metode Research and Development (R\&D). Secara umum, desain pengembangan yang digunakan dalam penelitian ini adalah 10 model Borg and Gall. Pada penelitian ini hanya menggunakan tiga tahap pertama dalam model Borg and Gall mengggunakan model ADDIE. Tiga tahap pertama dalam model Borg and Gall yakni Research and information collecting, Planning, Develop preliminary form of product. Selanjutnya model desain pengembangan yang digunakan model desain pengembangan ADDIE yang terdiri atas tiga tahap yaitu Analysis, Design, Development.

Teknik pengumpulan data pada penelitian ini adalah Teknik kuesioner. Teknik kuesioner yaitu teknik pengumpulan data dengan teknik non tes berupa kuesioner diperoleh hasil uji ahli materi dan hasil uji ahli media. Menurut (Sugiyono, 2014), kuesioner adalah teknik pengumpulan data dengan cara peneliti memberikan daftar pertanyaan atau pernyataan yang tertulis untuk dijawab oleh responden. Dalam penelitian ini, peneliti melakukan pembagian kuesioner secara langsung.

Data hasil validasi produk diperoleh dari ahli materi dan ahli media kemudian dianalisis menggunakan teknik deskriptif presentase dan kategori yang berguna untuk menggambarkan kelayakan uji coba produk. Skor hasil validasi materi dan validasi media dipresentasekan menggunakan rumus sebagai berikut:

Keterangan:

$$
\mathrm{AP}=\frac{\text { Skor Aktual }}{\text { Skor } \text { ideal }} \times 100 \%
$$

AP: Angka Presentase

Skor Aktual: Skor yang diberikan oleh validator ahli

Skor ideal: Skor maksimal hasil kali jumlah item dengan skor maksimal dari masing - masing item

Angka presentasi yang diperoleh selanjutnya dikelompokkan kedalam kriteria penilaian tabel 1 . 
Tabel 1

\begin{tabular}{ll}
\multicolumn{2}{c}{ Kategori Uji Validasi Ahli } \\
\hline \multicolumn{1}{c}{ Interval } & \multicolumn{1}{c}{ Kategori } \\
\hline $81-100 \%$ & Sangat Tinggi \\
\hline $61-80 \%$ & Tinggi \\
\hline $41-600 \%$ & Cukup \\
\hline $21-40 \%$ & Rendah \\
\hline $0-20 \%$ & Sangat Rendah \\
\hline
\end{tabular}

Hasil dari uji validasi materi dan validasi media dapat dikatakan layak untuk diujicobakan jika presentase minimal mencapai kategori tinggi yaitu $\geq 61 \%$ (Mawardi, 2014:113).

\section{HASIL DAN PEMBAHASAN}

Penelitian dan pengembangan media pembelajaran poly game pada pembelajaran matematika dalam meningkatkan kemampuan pemecahan masalah bangun datar siswa SD Kelas IV menggunakan tiga tahap pertama dalam model Borg and Gall yakni Research and information collecting, Planning, Develop preliminary form of product. Namun secara umum, desain pengembangan yang digunakan dalam penelitian ini adalah 10 model Borg and Gall yaitu Research and information collecting, Planning, Develop preliminary form of product, Preliminary field testing, Main product revision, Main field testing, Operational product revision, Operational field testing, Final product revision, dan Dissemination and implementation. Penelitian ini hanya menggunakan tiga tahap pertama dalam model Borg and Gall dan model ADDIE.

Pada tahap Research and information collecting dilakukan juga tahapan ADDIE yang pertama atau disebut Analisis. Tahap ini diperoleh ketika melakukan observasi dan memberikan angket kepada guru wali kelas IV. Tujuan menganalisis untuk menentukan masalah, memberikan solusi, dan menentukan kompetensi siswa. Hasil dari observasi didapatkan bahwa pembelajaran daring matematika pada materi bangun datar kelas IV hanya menggunakan media buku dan video pembelajaran dari youtube, sehingga membuat siswa kurang tertarik dan belum bisa meningkatkan kemampuan pemecahan masalah dalam materi bangun datar. Oleh sebab itu, diperlukan sebuah media yang dapat menarik dan meningkatkan kemampuan pemecahan masalah siswa. Media yang dikembangkan adalah media Poly Game yang mencakup materi serta latihan soal bangun datar. (Dalam angket di berikan tujuh pertanyaan antara lain 1. Apakah bapak/ibu memahami tentang game edukasi? Jawab : Tidak, 2. Apakah di sekolah bapak/ibu sudah ada game edukasi? Jawab : Tidak, 3. Berikan contohnya: -, 4. Apakah media yang digunakan saat pembelajaran daring sudah banyak? Jawab : Ya, 5. Berikan contohnya : Diambil dari video youtube (video pembelajaran), 6. Menurut bapak/ibu apakah perlu menggunakan game edukasi? Jawab: Ya, 7. Berikan alasannya: Agar siswa lebih paham mengenai materi ajar yang akan diajarkan, agar siswa lebih tertarik dengan pembelajaran, agar siswa tidak jenuh ketika pembelajarn sehingga hasil belajar akan maksimal.)

Pada tahap Planning dilakukan juga tahapan ADDIE yang kedua atau disebut Design. Tahap ini dengan menetapkan tujuan pembelajaran dengan menentukan kompetensi inti dan kompetensi dasar, merancang media dan perangkat pembelajaran yang disesuaikan dengan karakteristik peserta didik, membuat rancangan materi pembelajaran yang sesuai dengan media yang telah dirancang. Penelitian pengembangan yang berjudul "Pengembangan Media Poly Game pada Pembelajaran Matematika dalam Meningkatkan Kemampuan Pemecahan Masalah Bangun Datar Siswa SD Kelas IV" bertujuan untuk membantu siswa dalam memahami materi bangun datar sehingga siswa dapat meningkatkan kemampuan pemecahan masalah dalam materi bangun datar matematika. Produk yang dihasilkan dalam penelitian ini berupa game edukasi yaitu Poly Game, yang akan digunakan oleh siswa sekolah dasar.

Pada tahap Develop preliminary form of product dilakukan juga tahapan ADDIE yang ketiga atau disebut Development. Tahap ini menciptakan suatu media yang akan digunakan ketika kegiatan pembelajaran. Ada beberapa langkah dalam tahap pengembangan produk awal yaitu sebagai berikut; 1) Software dalam pembuatan 
Poly Game. Dalam pembuatan Poly Game menggunakan software Adobe Animate 2020. 2) Komponen komponen dalam Poly Game. Ada enam komponen dalam Poly Game yaitu halaman utama atau pembuka, halaman menu, petunjuk permainan, kompetensi dasar, materi pembelajaran, dan terakhir ada game. Petama, halaman utama. Pada tampilan utama terdapat judul dari game dan gambar loading. Kedua, halaman menu. Pada tampilan menu terdapat empat pilihan yaitu petunjuk, kompetensi dasar, materi pembelajaran, dan game. Ketiga, petunjuk permainan. Dalam petunjuk permainan terdapat cara - cara bermain dan fungsi dari navigasi yang terdapat dalam game. Keempat, kompetensi dasar. Pada tampilan kompetensi dasar terdapat 2 tampilan yang pertama menampilkan kompetensi dasar yang digunakan dalam game, kemudian yang slide kedua menampilkan indikator - indikator yang terdapat dalam game. Kelima, materi pembelajaran. Pada materi pembelajaran ini hanya menampilkan materi tentang bangun persegi panjang saja yang mencakup luas, keliling, ciri - ciri. Sebelum siswa melakukan permainan diharuskan mempelajari materi terlebih dahulu. Keenam, game. Pada tampilan game disajikan ikon yang akan dimainkan dengan beberapa rintangan berupa soal yang harus diselesaikan supaya dapat mencapai garis finish.

Spesifikasi produk media pembelajaran berbasis apk yang bernama Poly Game:

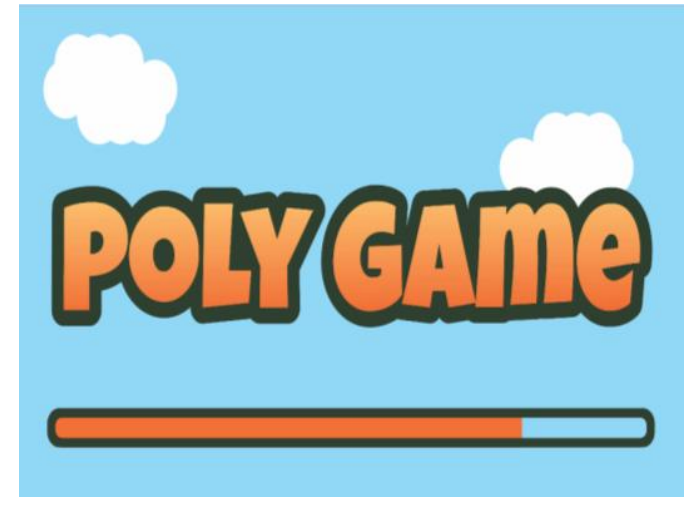

Gambar 1. Tampilan Awal Game

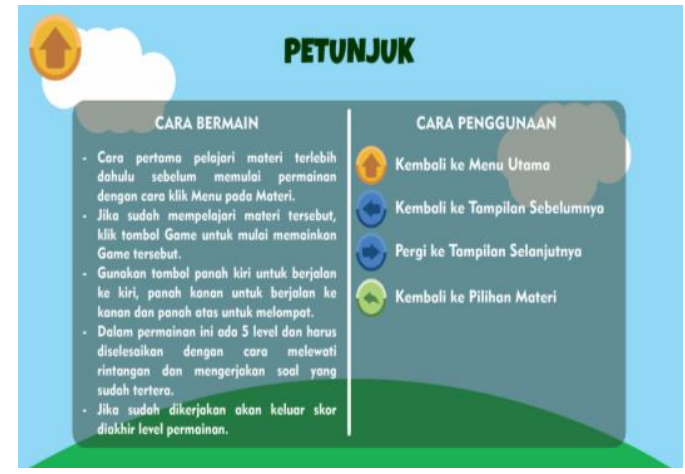

Gambar 3. Tampilan Petunjuk

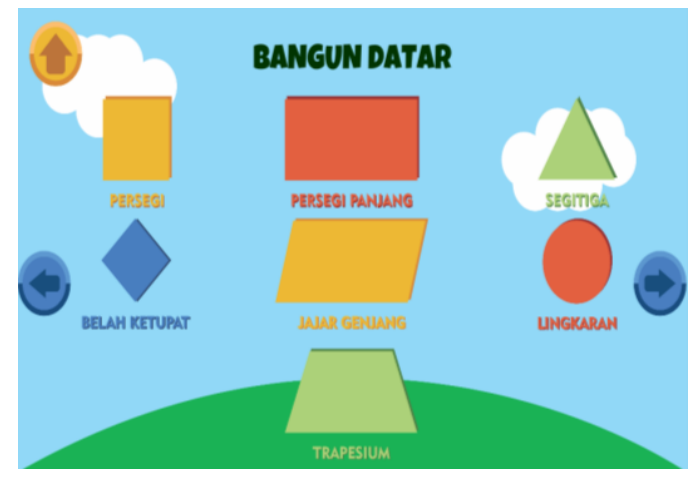

Gambar 5. Tampilan Materi Pembelajaran

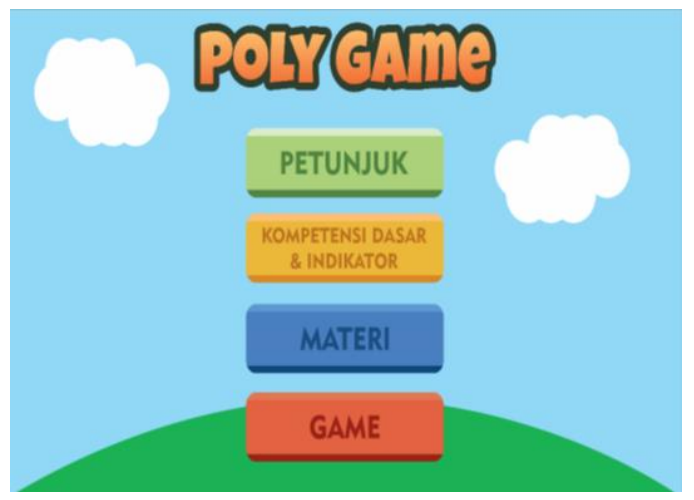

Gambar 2. Tampilan Menu Home

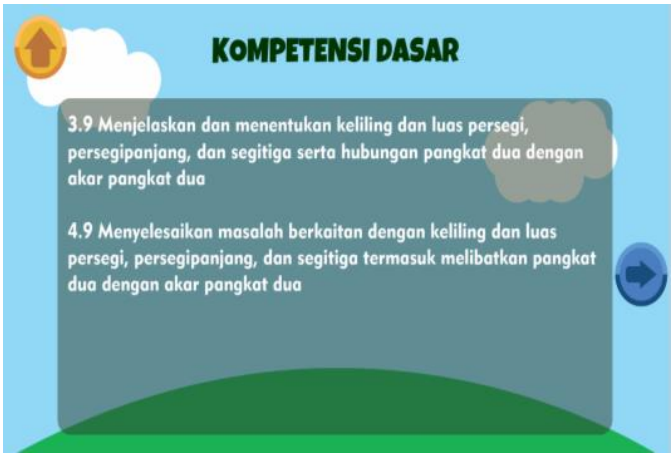

Gambar 4.Tampilan Kompetensi Dasar

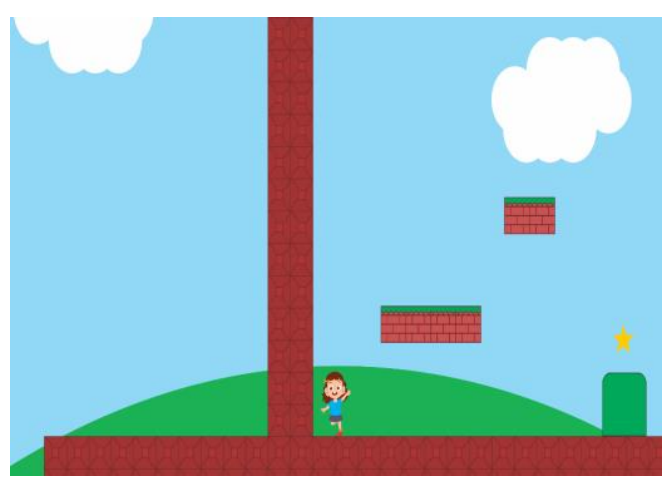

Gambar 6. Tampilan Game 
Pada tahap uji validasi ahli digunakan untuk memvalidasi produk media Poly Game yang dilakukan pada ahli materi dan ahli media. Tahap ini dilaksanakan dengan tujuan supaya Poly Game memperoleh saran dan kritik dari ahli pada bidang media maupun materi, sehingga Poly Game dapat layak digunakan dalam penelitian. Tahap uji validasi berguna untuk menilai produk berupa media pembelajaran poly game pada pembelajaran matematika dalam meningkatkan kemampuan pemecahan masalah bangun datar siswa SD Kelas IV. Uji validasi dilakukan oleh ahli yakni ahli materi dan ahli media.

Pada instrumen uji validasi ahli terdapat dua aspek di dalamnya. Pada instrumen uji ahli media aspek pertama berisi tentang media poly game antara lain tampilan, interaksi, desain materi pembelajaran, dan kontrol. Aspek yang kedua berisi tentang empat pemecahan masalah matematika menurut polya. Sedangkan instrumen uji ahli materi aspek yang pertama mengenai aspek materi antara lain relevansi, keakuratan, dan sistematika sajian. Aspek yang kedua juga berisi tentang empat pemecahan masalah matematika menurut polya. Berikut ini hasil uji validasi aspek yang pertama dari ahli media dan materi.

Tabel 2

Hasil Aspek Pertama Ahli Media

\begin{tabular}{ccc}
\hline Aspek & Persentase & Kriteria \\
\hline Tampilan & $91,6 \%$ & Sangat Tinggi \\
\hline Interaksi & $87,5 \%$ & Sangat Tinggi \\
\hline Desain Materi Pembelajaran & $87,5 \%$ & Sangat Tinggi \\
\hline Kontrol & $75 \%$ & Tinggi \\
\hline Rata rata & $85,4 \%$ & Sangat Tinggi \\
& Tabel 3 & \\
\hline Aspek & Hasil Aspek Pertama Ahli Materi & Kriteria \\
\hline Relevansi & Persentase & Sangat Tinggi \\
\hline Keakuratan & $83,3 \%$ & Tinggi \\
\hline Sistematika Sajian & $75 \%$ & Sangat Tinggi \\
\hline Rata rata & $100 \%$ & Sangat Tinggi \\
\hline
\end{tabular}

Hasil uji Validasi media pada aspek pertama yang terdiri dari empat aspek penilaian yaitu tampilan, interaksi, desain materi pembelajaran, dan control. Yang pertama pada aspek tampilan diperoleh presentase 91,6 $\%$ dengan kriteria sangat tinggi yang disebabkan oleh indicator media poly game sesuai dengan materi bangun datar serta indicator opening splash screen poly game dapat menarik siswa untuk belajar mendapatkan skor 4 . Yang kedua terdapat aspek interaksi yang memperoleh presentase 87,5\% dengan kriteria sangat tinggi, di dalam aspek interaksi terdapat indicator kesesuaian materi dengna topik game edukasi yang memperoleh skor 4 . Aspek yang ketiga adalah desain materi pembelajaran yang memperoleh presentase sebesar 87,5\% dengan kriteria sangat tinggi, di dalamnya tercantum indicator desain poly game yang membantu kejelasan tugas dalam game dan kesesuaian animasi dengan materi pembelajaran. Aspek yang terakhir adalah control yang mendapat presentase sebesar $75 \%$ dengan kriteria tinggi, masing - masing indicator yang terdapat pada aspek ini memperoleh skor 3. Selain itu validator media memberikan beberapa saran antara lain penulisan pada media Poly Game font yang digunakan terlalu kecil, tombol - tombol navigasi yang terdapat dalam Poly Game sebaiknya di variasi dan di warnai supaya lebih menarik. Berdasarkan presentase dari keempat aspek diperoleh rata - rata sebesar $85,4 \%$ dengan kriteria sangat tinggi.

Hasil uji validasi materi pada aspek yang pertama terdiri dari tiga aspek penilaian (Akbar, 2013) diantara lain relevansi, keakuratan, dan sistematika sajian. Pada aspek pertama yaitu relevansi memperoleh presentase 83,3\% dengan kriteria sangat tinggi, hal ini diperoleh dari indicator kesesuaian judul Poly Game dengan isi materi bangun datar. Selain itu terdapat indicator yang mendapat skor tiga dikarenakan kesalahan penulisan rumus keliling dan rumus luas persegi panjang. Kedua terdapat aspek keakuratan yang memperoleh presentase $75 \%$ dengan kriteria tinggi, ndicator yang tercantum ialah kesesuaian materi dnegan strategi polya. Aspek yang 
terakhir adalah sistematika sajian diperoleh presentase sebesar 100\% dengan kriteria sangat tinggi, presentase diperoleh dengan indicator penempatan materi yang disajikan sudah tepat. Ada beberapa saran yang diberikan oleh validator materi antara lain pada bagian materi masih kekurangan gambar ilustrasi, terdapat beberapa definisi yang masih salah, penulisan rumus harus sesuai dengan buku pedoman guru, background materi harus sesuai, poin - poin penting yang terdapat dalam materi diberikan warna yang berbeda, soal yang terdapat dalam game sebaiknya mempunyai tingkatan kesukaran, serta di akhir game harus memberikan reward. Dengan saran yang diberikan oleh ahli materi pembuatan produk Poly Game bertujuan untuk membantu peserta didik dalam memahami materi bangun datar persegi panjang dan peserta didik mampu meningkatkan kemampuan pemecahan masalah pada materi bangun persegi panjang. Berdasarkan presentase dari ketiga aspek materi diperoleh rata - rata sebesar $86,1 \%$ dengan kriteria sangat tinggi.

Tabel 4

Aspek Kedua Hasil Uji Validasi Materi dan Validasi Media tentang Pemecahan masalah matematika

\begin{tabular}{ccccccc}
\hline \multirow{2}{*}{ Aspek } & \multicolumn{2}{c}{ Ahli Media } & \multicolumn{2}{c}{ Ahli Materi } & \multicolumn{2}{c}{ Rata rata dari kedua Ahli } \\
\cline { 2 - 6 } & Persentase & Kriteria & Persentase & Kriteria & Persentase & Kriteria \\
\hline $\begin{array}{c}\text { Memahami } \\
\text { masalah }\end{array}$ & $75 \%$ & Tinggi & $87,5 \%$ & $\begin{array}{c}\text { Sangat } \\
\text { Tinggi }\end{array}$ & 81,25 & $\begin{array}{c}\text { Sangat } \\
\text { Tinggi }\end{array}$ \\
$\begin{array}{c}\text { Membuat } \\
\text { Perencanaan }\end{array}$ & $100 \%$ & $\begin{array}{c}\text { Sangat } \\
\text { Tinggi }\end{array}$ & $75 \%$ & Tinggi & $87,5 \%$ & $\begin{array}{c}\text { Sangat } \\
\text { Tinggi }\end{array}$ \\
\hline $\begin{array}{c}\text { Melaksanakan } \\
\text { Rencana }\end{array}$ & $100 \%$ & $\begin{array}{c}\text { Sangat } \\
\text { Tinggi }\end{array}$ & $75 \%$ & Tinggi & $87,5 \%$ & $\begin{array}{c}\text { Sangat } \\
\text { Tinggi }\end{array}$ \\
\hline Memeriksa & $100 \%$ & Sangat & $75 \%$ & Tinggi & $87,5 \%$ & Sangat \\
Kembali & & Tinggi & & & & Tinggi \\
\hline Rata-rata & $93,7 \%$ & Sangat & $78,1 \%$ & Tinggi & $85,9 \%$ & Sangat \\
& & Tinggi & & & & Tinggi \\
\hline
\end{tabular}

Aspek kedua tentang pemecahan masalah matematika. Hasil uji validasi media dengan empat aspek di dalamnya yaitu aspek memahami masalah yang mendapat presentase $75 \%$, aspek membuat perencaaan $100 \%$, aspek melaksanakan rencana $100 \%$, dan aspek memeriksa kembali mendapat presentase sebesar $100 \%$. Keempat presentase aspek yang diperoleh kemudian di rata - rata dan mendapat presentase sebesar 93,7\% dengan kriteria sangat tinggi. Hasil dari uji validasi materi dan validasi media dapat dikatakan layak untuk diujicobakan jika presentase minimal mencapai kategori tinggi yaitu $\geq 61 \%$ (Mawardi, 2014:113).

Hasil uji validasi materi dengan empat aspek yang sama antara lain aspek memahami masalah dengan presentase $87,5 \%$ dalam kriteria sangat tinggi, aspek membuat perencanaan mendapat presentase $75 \%$ dengan kriteria tinggi, ketiga terdapat aspek melaksanakan rencana memeproleh presentase sebesar $75 \%$ dengan kriteria tinggi. Dan yang terakhir aspek memeriksa kembali diperoleh presentase sebesar $75 \%$ dengan kriteria tinggi. Semua aspek kedua yang terdapat pada instrument uji validasi materi di rata - rata kemudian menghasilkan presentase $78,1 \%$ dengan kategori tinggi. Hal ini dikarenakan adanya kesalahan penulisan rumus dan kurang tepatnya penempatan gambar bangun datar dengan background pada poly game. Adapun saran yang di berikan oleh ahli materi antara lain (1) Dalam materi yang disajikan terlalu banyak tulisan sehingga kurang adanya gambar ilustrasi yang dapat membuat anak kurang menarik ketika membaca materi. (2) Definisi bangun datar sebaiknya menggunakan yang ada dalam buku pedoman guru. (3) Penulisan rumus luas dan keliling bangun datar harus sesuai dengan buku pedoman guru. (4) Background harus disesuaikan dengan materi sehingga tidak merusak konsep. (5) Penulisan poin - poin penting dalam definisi - definisi sebaiknya di berikan warna berbeda. (6) Soal yang disajikan dalam game harus menunjukkan tingkat kesukarannya seperti C4 sampai C6. (7) Diakhir game sebaiknya diberikan reward serta total skor dari level 1 sampai level 5. Selain itu dalam menyelesaikan masalah setidaknya terdapat 11 strategi menyelesaikan masalah menurut Reys (dalam Wahyudi \& Anugraheni, 2017) yaitu 1)Beraksi (Act It Out), 2)Membuat Gambar atau Diagram, 3)Mencari Pola, 4)Membuat Tabel, 5)Menghitung Semua Kemungkinan secara Sistematis, 6)Tebak dan Periksa (Uji) (Guess 
and Check), 7)Strategi Bekerja Mundur, 8)Mengidentifikasi Informasi yang Diinginkan, Diberikan, dan Butuhkan, 9)Menulis Kalimat terbuka, 10)Menyelesaikan Masalah yang Lebih Sederhana atau Serupa, 11)Mengubah Pandangan tetapi strategy ini tidak ada di poly game.

Berdasarkan presentase yang diperoleh dari uji validasi media sebesar 93,7\% dengan kategori sangat tinggi dan hasil uji validasi materi sebesar 78,1\% dengan kategori tinggi, maka dapat disimpulkan bahwa media pembelajaran poly game pada pembelajaran matematika dalam meningkatkan kemampuan pemecahan masalah bangun datar siswa SD Kelas IV dapat dikatakan layak untuk digunakan.

Pada Aspek Memahami Masalah, poly game memperoleh rata - rata presentase dari kedua ahli sebesar $81,25 \%$ yang termasuk dalam kriteria sangat tinggi, hal ini dikarenakan poly game membantu peserta didik dalam memahami permasalahan yang terdapat pada soal. Pada Aspek Membuat Perencanaan diperoleh dari presentase kedua ahli sebesar $87,5 \%$ dengan kriteria sangat tinggi, dalam poly game terdapat menu materi yang dapat mendorong siswa untuk mencari cara menyelesaikan masalah. Aspek Melaksanakan Rencana diperoleh presentasi dari kedua ahli sebesar $87,5 \%$, hal ini di karenakan poly game membantu siswa dalam melaksanakan suatu perencanaan untuk menyelesaikan soal atau masalah. Aspek terakhir yaitu Memeriksa Kembali, dengan adanya pembahasan soal dalam poly game membantu siswa untuk memeriksa kembali hasil yang telah diperoleh. Selain itu, dalam aplikasi poly game menyajikan informasi yang jelas pada soal sehingga siswa menjadi lebih memahami soal. Berikut contoh soal dan pembahasan soal yang terdapat dalam poly game.
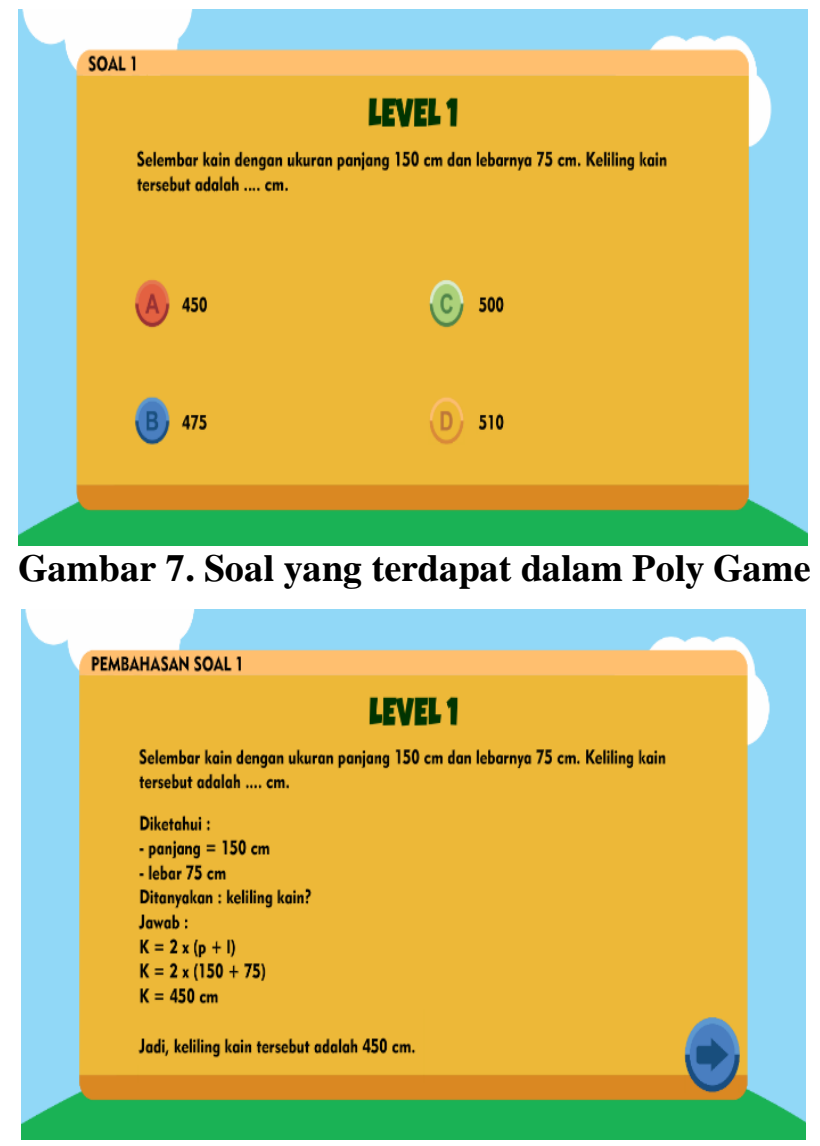

\section{Gambar 8. Pembahasan Soal yang terdapat dalam Poly Game}

Penelitian ini mengembangkan media pembelajaran poly game pada pembelajaran matematika dalam meningkatkan kemampuan pemecahan masalah bangun datar siswa SD Kelas IV. Dalam penggunaan media pembelajaran poly game pada pembelajaran matematika khususnya materi bangun datar dapat digunakan oleh siswa kelas IV SD, sehingga dengan adanya media pembelajaran poly game ini dapat membuat siswa bersemangat dalam mengikuti kegiatan pembelajaran. Kemudian siswa lebih mudah untuk memahami materi 
matematika khususnya materi bangun datar. Selanjutnya dengan adanya media pembelajaran poly game diharapkan membuat kemampuan pemecahan masalah bangun datar semakin meningkat. Selanjutnya media pembelajaran poly game juga memberikan pengalaman baru bagi siswa kelas IV, karena dengan adanya poly game ini membuat siswa belajar dengan hal baru yakni belajar menggunakan media pembelajaran poly game yang dapat dimainkan di PC seperti laptop dan komputer. Dengan adanya media pembelajaran poly game ini dapat membuat siswa berantusias untuk belajar dirumah kapan saja disertai bimbingan orangtua. Selain itu, media pembelajaran poly game juga dapat dijadikan sebuah referensi dan sumber belajar bagi guru dalam penggunaan media pembelajaran khususnya materi bangun datar.

Penelitian dan pengembangan media pembelajaran poly game pada pembelajaran matematika dalam meningkatkan kemampuan pemecahan masalah bangun datar siswa SD Kelas IV sesuai dengan penelitian yang dilakukan oleh Sejati (2020), bahwa pengembangan media pembelajaran basis PC game untuk meningkatkan kemampuan pemecahan masalah dinyatakan valid atau layak digunakan. Diperoleh dari hasil uji validasi materi seumlah $80 \%$, hasil uji validasi media $79,2 \%$, hasil uji validasi pembelajaran $81,2 \%$, dan hasil pakar soal 78,7 $\%$. Kemudian penelitian yang dilakukan oleh Savitri (2019), bahwa kevalidan media dapat ditemukan tiga jenis yaitu kelayakan, keefektifan, dan kepraktisan. Media interaktif dapat dikatakan "valid" dan "layak" oleh hasil penilaian dari para ahli media yang memperoleh rata - rata 3,4. Kemudian hasil respon angket dikategorikan "valid" dan" sangat praktis" yang memperoleh rata-rata 3,7. Dan tingkat keefktifan media memperoleh dari hasil tes 20 siswa dan dinyatakan "valid" dan "sangat efektif" dengan hasil rata - rata 82. Jadi dapat disimpulkan dari media interaktif materi luas dan keliling bangun datar dapat dikategorikan layak digunakan dilapangan. Selanjutnya penelitian yang dilakukan oleh Amanda \& Putri (2019), bahwa hasil dari menganalisis keunggulan aplikasi yang diperoleh dari hasil uji fuctional suitability memperoleh mendapat 86,6\% dan uji materi sejumlah $100 \%$. Serta hasil uji usability mendapat $93,7 \%$ dari uji coba pada siswa kelas IV. Dari penjelasan diatas dapat disimpulkan game edukasi mengenal bangun datar diakui layak atau valid untuk sarana media pembalajaran siswa kelas IV.

Media pembelajaran poly game pada pembelajaran matematika dalam meningkatkan kemampuan pemecahan masalah bangun datar siswa SD Kelas IV memiliki keterbatasan yakni media hanya dapat digunakan di PC seperti komputer dan laptop saja sehingga kurang fleksibel dalam penggunaannya. Kemudian hanya dapat digunakan pada materi bangun datar saja yang berisi soal pemecahan masalah. Dalam menginstal poly game membutuhkan kuota data yang cukup besar. Namun media pembelajaran poly game ini dapat dijadikan sebagai salah satu referensi atau sumber bagi guru dan sekolah khususnya pada matematika materi bangun datar.

\section{KESIMPULAN}

Penelitian ini dilakukan dalam rangka menjawab topik dan tujuan penelitian tentang validitas produk media pembelajaran poly game pada pembelajaran matematika dalam meningkatkan kemampuan pemecahan masalah bangun datar siswa SD Kelas IV. Media pembelajaran poly game pada pembelajaran matematika dalam meningkatkan kemampuan pemecahan masalah bangun datar siswa SD Kelas IV telah melalui tahap uji validasi dari ahli materi dan ahli media menggunakan dua aspek. Presentase yang diperoleh dari uji validasi materi sebesar sebesar 78,1\% dengan kategori tinggi. Sedangkan presentase yang diperoleh dari uji validasi media sebesar 93,7\% dengan kategori sangat tinggi. Berdasarkan uji validasi yang telah dilakukan oleh ahli materi dan ahli media, maka dapat disimpulkan bahwa media pembelajaran poly game pada pembelajaran matematika dalam meningkatkan kemampuan pemecahan masalah bangun datar siswa SD Kelas IV dapat dikatakan valid untuk digunakan. Peneliti menyarankan adanya penelitian lanjut terkait efektifitas produk pada pengguna Poly Game, dalam hal ini siswa kelas IV dalam peningkatan kemampuan pemecahan masalah.

\section{DAFTAR PUSTAKA}

Akbar. (2013). Instrumen perangkat pembelajaran. PT. Remaja Rosdakarya. 
2460 Pengembangan Media Poly Game pada Pembelajaran Matematika Dalam Meningkatkan Kemampuan Pemecahan Masalah di Sekolah Dasar - Denise Dwi Rahmatania, Yohana Setiawan

DOI: https://doi.org/10.31004/basicedu.v5i4.1249

Amanda, D. A., \& Putri, A. R. (2019). Pengembangan Game Edukasi Pada Mata Pelajaran Matematika Materi Bangun Datar Berbasis Android di SDN 1 Jepun. JOEICT (Jurnal of Education and Information Communication Technology), 3(2), 160-168.

Anisah, M. dan. (2015). Kemampuan Pemecahan Masalah Matematis Siswa Pada Pembelajaran Matematika Dengan Menggunakan Model Pembelajaran Generatif (Generative Learning) di SMP. Jurnal Pendidikan Matematika FKIP Universitas Lambung Mangkurat, 3(2).

Anugrahini, Y. \& Windrawanto, Y. (2017). Pengembangan Game Bubble Match Sebagai Media Pembelajaran Pembagian dalam Bentuk Pengurangan Berulang Untuk Siswa Kelas 2 SD. Jurnal Profesi Pendidikan Dasar, 4(1), 75-83.

Ardiansyah, I. (2013). Eksplorasi Pola Komunikasi dalam Diskusi Menggunakan Moddle pada Perkuliahan Simulasi Pembelajaran Kimia. Universitas Pendidikan Indonesia.

Depdiknas. (2003). Undang-undang RI No.20 tahun 2003.tentang sistem pendidikan nasional.

Desi Indarwati, Wahyudi, N. R. (2014). Peningkatan Kemampuan Pemecahan Masalah Matematika Melalui Penerapan Problem Based Learning Untuk Siswa Kelas V SD. Jurnal Penelitian Pengembangan Kependidikan, 30(1), 17-27.

Kosasih. (2014). Strategi Belajar dan Pembelajaran Implementasi Kurikulum 2013. Yrama Widya.

Kuncoro, Y. (2019). Pengembangan game pembelajaran matematika untuk siswa kelas IV SD dengan menggunakan program Visual Scratch. Skripsi thesis, Sanata Dharma University.

Mastura, M., \& Santaria, R. (2020). Dampak Pandemi Covid-19 terhadap proses Pengajaran Bagi Guru dan Siswa. Jurnal Studi Guru Dan Pembelajaran, 3(2), 289-295.

Mawardi. (2014). Model Desain Pembelajaran Kosep Dasar PKn Berbasis Belajar Mandiri Menggunakan Moodle. Widya Sari Press.

Prensky, M. (2012). From Digital Natives to Digital Wisdom.

Savitri, E. H. (2019). Pengembangan Media Interaktif Berbasis APP Desktop Materi Luas Dan Keliling Bangun Datar Siswa Kelas IV SDN Wunut 1 Kecamatan Porong Kabupaten Sidoarjo Pendidkan Guru Sekolah Dasar Universitas Kanjuruhan Malang Email : estryhutamisavitri@yahoo.co.id Pendi. Seminar Nasional PGSD UNIKAMA, 3(November), 467-476.

Sejati, K. A. P. (2020). Pengembangan Model Media Pembelajaran Berbasis PC Game Untuk Meningkatkan Kemampuan Pemecahan Masalah Materi Bangun Datar. Jurnal CendekiaJ:Urnal Pendidikan Matematika, 4(2), 602-614. https://doi.org/https://doi.org/10.31004/cendekia.v4i2.279

Shadiq, F. (2014). Pembelajaran Matematika (Cara Meningkatkan Kemampuan Berpikir Siswa). Graha Ilmu.

Sugiyono. (2014). Metode Penelitian Pendidikan Pendekatan Kuantitatif, Kualitatif, dan R\&D. Alfabeta.

Tri, W. (2011). Pengembangan Student Worksheet Berbahasa Inggris SMP Kelas VIII Pada Pembelajaran Aljabar Pokok Bahasan Sistem Persamaan Linear Dua Variabel dengan Pendekatan Pemecahan Masalah Berbasis Kontruktivisme. Universitas Negeri Yogyakarta.

Wahyudi, W., \& Anugraheni, I. (2017). Strategi Pemecahan Masalah Matematika. In Satya Wacana University Press (Issue August). https://herryps.files.wordpress.com/2010/09/strategi-pemecahan-masalahmatematika.pdf

Widyastuti, dkk. (2019). Minat Siswa Terhadap Matematika dan Hubungannya dengan Metode Pembelajaran dan Efikasi Diri. Jurnal Pendidikan Matematika, 13(1), 83-100.

Zulkarnain. (2015). Pendidikan Kognitif Berbasis Karakter. Tasamuh: Jurnal Komunikasi Dan Pengembangan Masyarakat Islam IAIN Mataram, 12(2), 189-203. 